\title{
PERIMBANGAN KEUANGAN ANTARA PUSAT DAN DAERAH: TRANSFER PUSAT KE DAERAH, PEMERATAAN KEUANGAN DAERAH DAN KAPASITAS DAERAH
}

\author{
Harsanto Nursadi ${ }^{1}$
}

\begin{abstract}
Abstrak
Currently, the transfer of funds from the Central to Local Government always leads the local financial structure. Local Government is most dependent toward the amount of transfer funds. The result is the region becomes not independent, and as it goes, by regional autonomy is not able to perform optimally. This research also shows that only a few regions that have large Regional Revenue (PAD) and not much dependent with the transfer of the Central Government. Of the various problems that arise on the transfer of funds to region in the balance fund (dana perimbangan), then amount of transfer to region has annual range in the $30 \%$. If the number is viewed cumulatively both percentage and value, is the third of the total State budget each year. A relatively small number be given but also being attached immensely regional affairs obliged and 'certain threats' if they won't to carry it.
\end{abstract}

Kata kunci: hukum administrasi negara, perimbangan keuangan, pemerataan, kapasitas

\section{Pendahuluan}

Sejak decentralisatie wet diterapkan pada tahun 1903, hubungan keuangan sudah terjadi antara Pemerintah Pusat dengan daerah (gewest atau bagian-bagian dari gewest) yang dimungkinkan dibentuk daerah otonom. Namun pada saat itu belum jelas sistem, prinsip, bentuk dan jenis anggaran yang digunakan. Periode berlakunya suatu anggaran juga belum ditetapkan dan didefinisikan secara jelas. Demikian juga pada saat pendudukan Jepang, sistem keuangan menjadi semakin tidak jelas, karena Jepang merubah secara fundamental susunan dan tata administrasi pemerintahan sipil menjadi pembagian wilayah kekuasaan militer. ${ }^{2}$

${ }^{1}$ Penulis adalah Staf Pengajar Fakultas Hukum Uinversitas Indonesia. Alamat korespondensi: santo_hn@yahoo.com. 
Ketika Indonesia merdeka, maka hal keuangan mulai jelas diatur dalam Pasal 23 Bab VIII UUD 1945, dan sistem keuangan daerah juga mulai diatur dengan UU No. 1 Tahun 1945, yaitu pada pasal 5 yang menyebutkan bahwa biaya untuk keperluan Komite Nasional Daerah (KND) disediakan oleh Pemerintah Daerah dan apabila terdapat kekurangan akan ditanggung oleh Pemerintah Pusat (sluit spot) dengan soft budget control dan sistem yang dipergunakan adalah anggaran berimbang. Waktu anggarannya adalah tahunan tanpa diatur dengan jelas formal periode waktunya. Bentuk dan jenis anggaran belum didefinisikan secara jelas. ${ }^{3}$

Pengaturan mulai jelas setelah diberlakukannya UU No. 22 Tahun 1948, yaitu mulai berlakunya periode anggaran pada 1 Januari sampai 31 Desember. Hubungan Keuangan yang terjadi antara Pemerintah ${ }^{4}$ dan Daerah ${ }^{5}$ disebut dengan hard budget control, dan dengan pelaksanaan yang masih sluit spot, sistem yang terus dipakai sampai UU No. 5 Tahun 1974. Pada pelaksanaannya, UU No. 18 Tahun 1965 mengatur lebih rinci mengenai penggunaannya, yaitu, mulai dilaksanakannya dual budgeting yaitu berlakunya anggaran rutin dana anggaran pembangunan dan periode anggaran berubah menjadi 1 April sampai dengan 31 Maret. Hal lain yang juga diatur adalah harus terjadinya keseimbangan (balance budget) antara penerimaan dan belanja dalam suatu anggaran (baik APBN maupun APBD), yang berlaku sampai UU No. 5 Tahun 1974.

Perubahan kembali terjadi pada tahun 1999, ketika mulai diberlakukannya UU No. 22 Tahun 1999 tentang Pemerintahan Daerah dan UU No. 25 Tahun 1999 tentang Perimbangan Keuangan antara Pemerintah dan Daerah, yaitu Sistem soft budget control (sliut spot) ${ }^{6}$ diubah kembali menjadi hard budget control ${ }^{7}$ dengan masa anggaran berubah menjadi 1 Januari sampai dengan 31 Desember. Bentuk lain yang berubah adalah sistem $T$-account ${ }^{8}$ yang selama ini dipakai berubah menjadi I-account ${ }^{9}$

257.

${ }^{2}$ Safri Nugraha, dkk, "Hukum Administrasi Negara", (Jakarta: CLGS, 2007), hal.

${ }^{3}$ Ibid.

${ }^{4}$ Penulisan Pemerintah dengan huruf $\mathrm{p}$ besar $(\mathrm{P})$, menunjukkan Pemerintah Pusat.

${ }^{5}$ Penulisan Daerah dengan huruf $\mathrm{d}$ besar (D), menunjukkan daerah otonom.

${ }^{6}$ Kekurangan anggaran daerah ditanggung pusat.

${ }^{7}$ Kekurangan anggaran ditanggung pusat.

${ }^{8}$ Sisi kiri penerimaan dan sisi kanan adalah pengeluaran. 
menyesuaikan dengan perkembangan sistem dan standar klasifikasi anggaran internasional. Perubahan tersebut berdampak pada prinsip anggarannya, yaitu dari balance budget berubah menjadi dificit-surplus budget.

Transfer dana dari Pemerintah ke Daerah menunjukkan dimulainya suatu hubungan keuangan antara pusat dan daerah. Tranfer tersebut diperlukan ${ }^{10}$ karena pertama untuk mengatasi persoalan ketimpangan vertikal fiskal. ${ }^{11}$ Kedua, untuk mengatasi horizontal fiskal. ${ }^{12}$ Ketiga, daerah wajib menjaga tercapainya standar pelayanan minimal di setiap daerah. ${ }^{13}$ Keempat, untuk mengatasi persoalan yang timbul dari menyebarnya atau melimpahnya efek pelayanan publik ${ }^{14}$ (interjurisdictional spill over effect), dan kelima untuk rehabilitasi ${ }^{15}$ serta keenam, "mengedukasi-mendorong" pemerintah daerah untuk terus meningkatkan kemampuan daerahnya. Kriteria umum dalam desain transfer pusat ke daerah adalah otonomi, penerimaan yang

${ }^{9}$ Sistem dual budgeting (anggaran rutin dan pembangunan) atau unified budgeting (anggaran terpadu).

10 Robert A. Simanjuntak, "Transfer Pusat ke Daerah: Konsep dan Praktik di Beberapa Negara," dalam Machfud Sidik et.al (eds), "Dana Alokasi Umum (DAU): Konsep, Hambatan dan Prospek di Era Otonomi Daerah", (Jakarta: Penerbit Buku Kompas), hal 23, dikutip pula pada Safri Nugraha, dkk, "Hukum Administrasi Negara", (Jakarta: CLGS, 2007), hal. 260

${ }^{11}$ Dibanyak negara termasuk Indonesia, pemerintah pusat menguasai sebagian besar sumber-sumber penerimaan (pajak) untuk negara yang bersangkutan dan pemerintah daerah hanya menguasai sebagian kecil sumber-sumber penerimaan negara atau hanya berwenang unuk memungut pajak-pajak yang basis pajaknya lokal dan mobilitasnya rendah dengan karakteristik besaran penerimaan relatif kurang signifikan.

${ }^{12}$ Kemampuan daerah untuk menghimpun pendapatan daerah sangat bervariasi tergantung kepada kondisi daerah bersangkutan yang memiliki atau tidak sumber daya alam, atau intensitas kegiatan ekonominya tinggi atau rendah. Selain itu juga tergantung dari kebtuhan belanja untuk pelaksanaan berbagai fungsi dari pelayanan publik.

${ }^{13}$ Daerah yang memiliki sumber daya yang sedikit memerlukan subsidi dari pusat untuk menjalankan standar pelayanan minimum, dan Musgrave menyatakan bahwa redistributif dari sektor publik akan lebih efektif dan cocok bila dilakukan oleh pemerintah pusat.

${ }^{14}$ Pelayan publik di suatu daerah memiliki efek yang menyebar ke wilayah-wilayah lain, seperti rumah sakit/daerah, jalan tol, universitas, pemadam kebaran, yang tidak boleh dibatasi hanya boleh dimanfaatkan oleh masyarakat daerah tertentu saja

15 Pemerintah pusat dapat mentranfer dana ke suatu daerah untuk mendorong perekonomian daerah tersebut untuk kembali meningkat, dan ketika sudah baik, tranfer dapat dialihkan atau dikurangi untuk daerah lain. 
memadai (revenue adequacy), keadilan (equity), transparan dan stabil, sederhana (simplicity) dan insentif.

Dari sisi Daerah, suatu daerah dapat disebut otonom bila memenuhi beberapa kriteria sebagai berikut: 1. Sebagai suatu zelfstandigestaatsrechtelijke organisatie yang dicerminkan pada keuangan, pembiayaan dan dimilikinya Dinas Daerah. ${ }^{16}$ 2. Dari sisi hukum: adalah badan hukum (rechtspersoon), sehingga memiliki kuasa untuk melakukan tindakan-tindakan mengenai kekayaan (vermogensrecht), kekuasaan hukum (rechtsbevoegd) dan dapat bertindak (handelingsbekwaam). ${ }^{17}$ 3. Sebagai badan hukum dapat dituntut dan menuntut pihak lain dipengadilan, memiliki anggaran sendiri dengan rekening yang terpisah dari rekening Pemerintah Pusat, memiliki wewenang untuk mengalokasikan sumber-sumber yang substansial, ${ }^{18} 4$. Mengemban multifungsi yang merupakan pembeda utama antara daerah otonom dengan lembaga yang terbentuk dalam rangka desentralisasi fungsional. 5. Penyelenggara desentralisasi adalah Pemerintah Pusat. ${ }^{19}$

Salah satu kriteria ke tiga, yaitu memiliki anggaran sendiri dengan rekening yang terpisah dari rekening Pemerintah Pusat dan memiliki wewenang untuk mengalokasikan sumber-sumber yang substansial. Artinya bahwa Daerah harus mampu untuk mengelola dan menggunakan sumbersumber yang ada di daerahnya dan mengurangi sekecil mungkin ketergantungan dari pemerintah pusat.

Kriteria tersebut telah dipenuhi oleh semua Daerah di Indonesia dengan disahkannya Anggaran Pendapatan dan Belanja Daerah (APBD) setiap tahunnya yang dibahas dan ditetapkan bersama oleh DPRD dan

16 J.H.A. Logeman, "Het Staatsrecht van Indonesia: Het Formele Systeem", (SGravenhage/Bandung: N.V. Uitgevrijk W. van Hoeve, 1954, p. 158 dalam Bhenyamin Hoessein, "Berbagai Faktor Yang Mempengaruhi Besarnya Otonomi Daerah Tingkat II, Suatu Kajian Desentralisasi dan Otonomi Daerah Dari Segi Ilmu Administrasi Negara, Disertasi Pascasarjana UI, 1993, hal. 15.

17 Jodi Gondokusimo, "Tata Hukum Daerah Otonom", (Yogyakarta: Menara Pengetahuan, 1950), hal.28 dalam Bhenyamin Hoessein, Berbagai Faktor Yang Mempengaruhi Besarnya Otonomi Daerah Tingkat II, Suatu Kajian Desentralisasi dan Otonomi Daerah Dari Segi Ilmu Administrasi Negara, Disertasi Pascasarjana UI, 1993, p. 15 dan 16.

${ }^{18}$ Philip Mawhood et., al., "Local Government In The Third Word", (New York: John Wiley \& Sons, 1983), p. 9, dalam Bhenyamin Hoessein, Loc., Cit., hal. 16.

19 Yang berarti penetapan strategi, kebijaksanaan dan program termasuk pembentukan peraturan perundang-undangan dan daerah otonom beserta penyerahan wewenang serta pengembangannya. 
Kepala Daerah. ${ }^{20}$ Pada APBD tersebut terdapat tiga struktur, yaitu Sisi Penerimaan, Sisi Pengeluaran dan Sisi Pembiayaan. Pada sisi penerimaan sebuah APBD terdapat sumber pendapatan daerah, yaitu berupa Pendapatan Asli Daerah, Dana Perimbangan dan Lain-lain pendapatan daerah yang sah. Pada dana perimbangan itulah terdapat transfer dana dari Pemerintah kepada Daerah.

Saat ini, transfer dana dari Pemerintah kepada Daerah, selalu mendominasi struktur keuangan daerah. Daerah terlalu tergantung dari besaran dana transfer tersebut. Akibatnya adalah Daerah menjadi tidak mandiri, dan sebagai kelanjutannya, Daerah tidak mampu menjalankan otonomi yang dimilikinya secara optimal. Pada tabel 1 , menunjukkan bahwa hanya beberapa Daerah saja yang memiliki Pendapatan Asli Daerah yang besar dan tidak terlalu tergantung dengan transfer dari Pemerintah.

Pada sisi yang lain, Pemerintah pada APBNnya selalu membagi anggaran belanja negaranya dalam bentuk transfer ke Daerah dalam bentuk total dana perimbangan sebesar kurang lebih 30\% (lihat tabel 1) Di dalam besaran tersebut, sebenarnya belum terpenuhinya kewajiban Pemerintah berdasarkan UU No. 33 Tahun 2004, bahwa Dana Alokasi Umum, ditetapkan sekurang-kurangnya 26\% (dua puluh enam persen) dari Pendapatan Dalam Negeri Neto yang ditetapkan dalam APBN. ${ }^{21}$

Besaran transfer ke Daerah, yang sebenarnya merupakan bagian dari money follow function dari sejumlah urusan yang saat ini menjadi kewenangan Daerah, merupakan permasalahn tersendiri. Disisi lain, angka $30 \%$ dari total pendapatan Negara yang ditransfer ke Daerah nampaknya juga merupakan hal yang sulit untuk ditambah, mengingat beban Pemerintah terhadap tugas-tugas pemerintahan yang lain.

${ }^{20}$ Indonesia, Undang-undang No. 32 Tahun 2004 tentang Pemerintahan Daerah, pasal 25 huruf D.

${ }^{21}$ Indonesia, Undang-undang No. 33 Tahun 2004 tentang Perimbangan Keuangan antara Pemerintah Pusat dan Pemerintah Daerah, psl. 27 ayat (1). 
TABEL 1

APBN 2005 S.D. 2010 DAN TRANSFER KE DAERAH

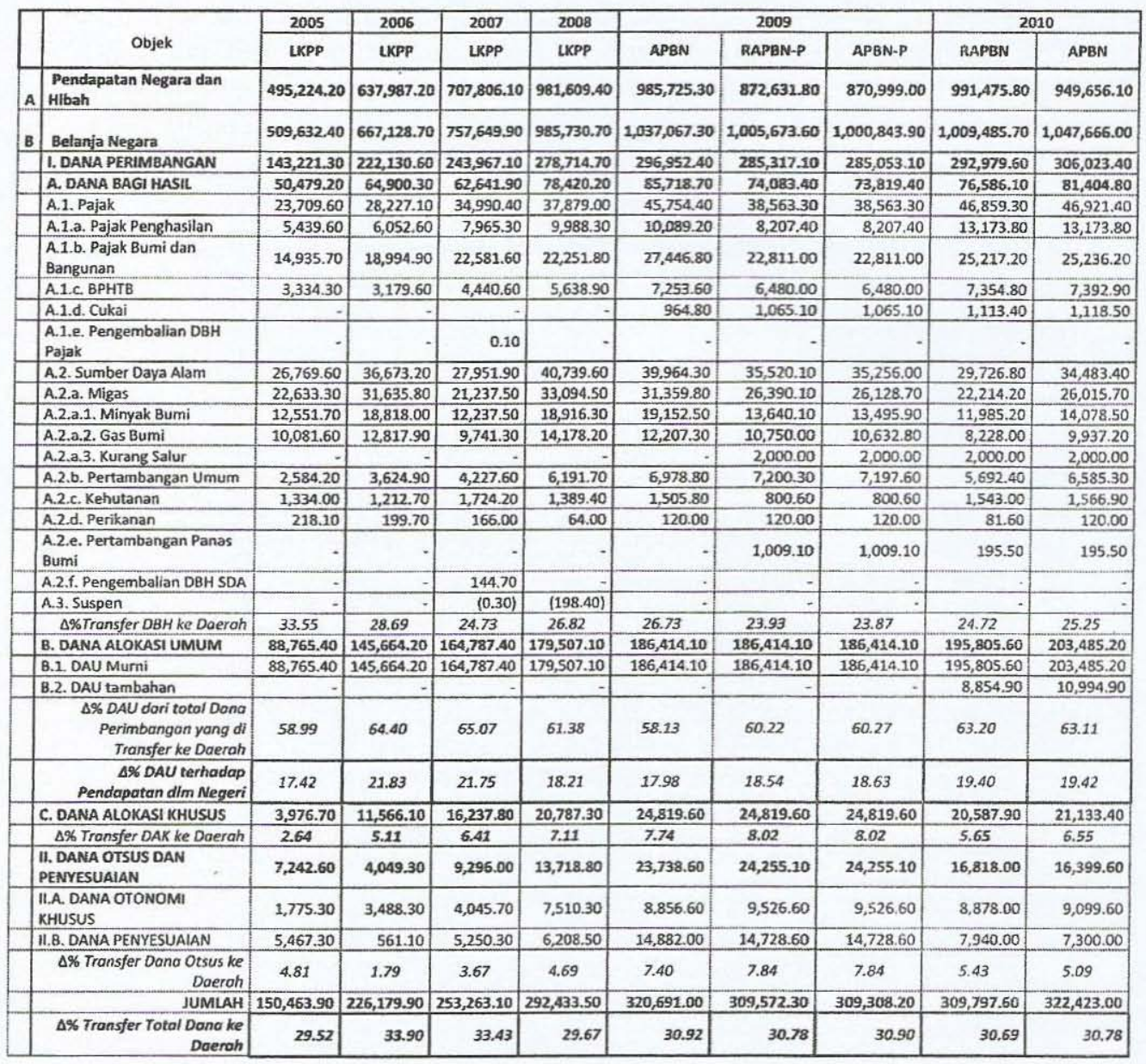

\section{Permasalahan}

Pada prakteknya, permasalahan perimbangan keuangan antara Pemerintah dan Daerah ini menjadi hal yang penting, dan bahkan dalam halhal tertentu dapat memancing konflik antara Pemerintah dengan Daerah. Terhadap daerah-daerah yang memiliki sumber daya alam yang banyak, seperti minyak bumi, panas bumi, hutan, pertambangan, tentunya menuntut dana yang lebih besar dibandingkan dengan daerah-daerah yang tidak memiliki. Tetapi permasalahannya adalah bagaimana dengan daerah-daerah yang tidak memiliki sumber daya alam? Apakah daerah-daerah tersebut kemudian dibiarkan menjadi daerah miskin? Sebagai suatu Negara Kesatuan, 
maka memang menjadi tugas Negara yang dijalankan oleh Pemerintah untuk menjaga keseimbangan antara satu daerah dengan daerah yang lain, terutama antara daerah yang memiliki pendapatan asli daerah yang besar termasuk keberadaan sumber daya alamnya dengan daerah-daerah yang tidak memiliki. Pertanyaan berikutnya adalah, sudah seimbangkah apa yang diatur oleh Pemerintah selama ini?

\section{Perimbangan Keuangan: Transfer dan Pemerataan}

\section{A. Konsep dan Kebutuhan}

Sesuai asas money follows function, penyerahan kewenangan daerah juga dibarengi dengan penyerahan sumber-sumber pembiayaan yang pada pengaturan UU 5 tahun 1974 dipegang oleh Pemerintah Pusat. Diharapkan Daerah mampu untuk melaksanakan segala urusannya sendiri sebab sumber-sumber pembiayaan juga sudah diserahkan. Jika mekanisme tersebut sudah terwujud maka cita-cita kemandirian Daerah dapat direalisasikan.

Sumber-sumber pembiayaan yang diserahkan kepada Daerah itu nantinya akan dimanifestasikan lewat struktur PAD yang kuat. PAD inilah sumber pembiayaan yang memang benar-benar digali dari Daerah itu sendiri sehingga dapat mencerminkan kondisi riil Daerah. Jika nantinya struktur PAD sudah kuat, boleh dikatakan Daerah tersebut memiliki kemampuan pembiayaan yang juga kuat. Untuk itu tentu dibutuhkan suatu struktur industri yang mantap beserta obyek pajak dan retribusi yang taat. Sementara DAU dan berbagai bentuk transfer dari Pemerintah Pusat seyogyanya hanya bersifat pendukung bagi pelaksanaan pemerintahan dan pembangunan di daerah.

Sebagai suatu sistem pembiayaan pemerintahan dalam kerangka negara kesatuan, yang mencakup pembagian keuangan antara Pemerintah Pusat dan Daerah serta pemerataan antar Daerah secara adil dan proporsional, demokratis dan transparan, dengan tetap memperhatikan potensi, kondisi dan kebutuhan Daerah sejalan dengan kewajiban dan pembagian kewenangan serta tata cara penyelenggaraan kewenangan tersebut termasuk pengelolaan dan pengawasan keuangannya Dana Perimbangan bertujuan mengurangi kesenjangan fiskal antara Pemerintah dan Pemerintahan Daerah dan antarPemerintah Daerah.

Perimbangan Keuangan antara Pemerintah dan Pemerintahan Daerah merupakan bagian pengaturan yang tidak terpisahkan dari sistem Keuangan Negara, dan dimaksudkan untuk mengatur sistem 
pendanaan atas kewenangan pemerintahan yang diserahkan, dilimpahkan, dan ditugas bantukan kepada Daerah.

\section{B. Sumber Pendapatan Daerah}

Komponen sumber pendapatan daerah adalah terdiri dari: 1 . Pendapatan Asli Daerah yang termasuk didalamnya adalah Hasil pajak daerah, Hasil retribusi daerah, Hasil pengelolaan kekayaan daerah yang dipisahkan; ${ }^{22}$ dan Lain-lain PAD yang sah. 2. Dana Perimbangan dan Lain-lain pendapatan daerah yang sah. Berdasarkan komponen sumber pendapatan daerah tersebut, maka dewasa ini ketergantungan Daerah pada dana perimbangan masih sangat significant. Hampir seluruh Daerah di Indonesia menunjukkan fakta bahwa PAD yang dimiliki Daerah sangat kecil dan variable yang terbesar pada sisi pendapatan daerah adalah dana yang berasal dari dana perimbangan.

Bila kita mengambil contoh pelaksanaan APBD 2009 oleh Daerah Provinsi di Indonesia, maka akan terlihat persentase yang besar dari peran dana perimbangan tersebut. Tabel 2 menunjukkan hal tersebut, yaitu bila kita melihat persentase antara besarnya dana perimbangan dengan total pendapatannya, maka akan terlihat Provinsi Gorontalo menempati urutan teratas, yaitu $85,60 \%$ sisi pendapatan daerahnya berasal dari dana perimbangan atau senilai Rp.457,525 M. Pendapatan asli daerah pada provinsi ini adalah sebesar Rp.76,980 M, atau sebesar $14,4 \%$ saja dari sisi pendapatan pada APBD.

DKI Jakarta sebagai Daerah dengan nilai APBD sebesar Rp.20,674 T, pendapatan asli daerahnya sebesar 53,86\% atau sebesar Rp.11,134 T. Dana bagi hasil pajak bagi Provinsi DKI terbesar berasal dari bagi hasil pajak, yaitu sebesar Rp.9,540 T atau 46,14\%. Bagi hasil pajak di Provinsi DKI memang luar biasa, karena memang kira-kira $90 \%$ perputaran uang di Negara ini berada di DKI Jakarta. ${ }^{23}$

Provinsi Nangroe Aceh Darusalam dan Propinsi Papua dan Papua Barat, memiliki struktur yang bebeda dengan DKI, karena kedua daerah tersebut, mendapatkan dana otonomi khusus dan dana penyesuaian yang nilainya cukup significant. Pada Provinsi Nagroe

\footnotetext{
${ }^{22}$ Antara lain bagian laba dari BUMD, hasil kerjasama dengan pihak ketiga

${ }^{23}$ Sebagai iluststrasi pada APBD DKI 2008: PAD yang berasal dari Pajak Daerah
} sebesar $81,72 \%$ dari total pendapatan atau senilai $\mathrm{Rp} 8,484 \mathrm{~T}$; Retribusi Daerah sebesar 3,50 atau senilai Rp 363,568 M; Hasil pengelolaan kekayaan daerah yang dipisahkan sebesar $1,65 \%$ atau senilai $\mathrm{Rp} 170,976 \mathrm{M}$ dan Lain-lain Pendapatan Daerah yang sah sebesar $13,13 \%$ atau senilai Rp 1,362 T dari total PAD sebesar Rp 10,381 T. Tabel 2 adalah APBD DKI 2009. 
Aceh Darusalam, PAD yang dimiliki senilai Rp.795,872 M atau sebesar $11,82 \%$ dari total pendapatan, dana perimbangan senilai Rp.2,208 T atau sebesar $32,80 \%$ dan dana Otonomi khusus dan penyesuian senilai Rp.3,728 $\mathrm{T}$ atau sebesar $55,38 \%$ dari total pendapatan.

Pada Provinsi Papua, PAD yang dimiliki adalah senilai $\mathrm{Rp}$ 345,398 M atau sebesar 6,49\%, Dana Perimbangan senilai Rp.1,566 T atau sebesar $29,44 \%$ dan dana Otonomi Khusus dan penyesuaian senilai Rp.2,609 T atau sebesar 49,04\% dari total pendapatan daerahnya Rp.5.322 T. Sedangkan pada Papua Barat, PAD nya senilai Rp.44,506 $M$ atau sebesar 2,25\%, Dana Perimbangan senilai Rp. $197,780 \mathrm{M}$ atau sebesar 6,86 \% dan dana Otomi Khusus senilai Rp.1,718 T atau sebesar 59,64\% dari total pendapatan senilai Rp.2,881 T. 
TABEL 2

SUMBER PENDAPATAN DAERAH Pada APBD PROMNSI 2009

\begin{tabular}{|c|c|c|c|c|c|c|c|c|c|c|}
\hline & Daerah & PAD & 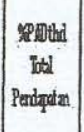 & $\begin{array}{c}\text { Dana } \\
\text { Perimbangan }\end{array}$ & 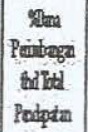 & $\begin{array}{l}\text { DBH pajak/ } \\
\text { bukanpajak }\end{array}$ & DAU & DAK & \begin{tabular}{|c|} 
Dana \\
penyesuaian \\
dan ototsus
\end{tabular} & $\begin{array}{c}\text { TOTAL } \\
\text { PENDAPATAN }\end{array}$ \\
\hline 10 & Nama & 2 & & 7 & & 8 & 9 & 10 & 16 & 19 \\
\hline 1. & Prow. Nanggroe Aceh Darussalam & 795,872 & 11.82 & 2208,058 & 328 & $1,650,183$ & 509,686 & 48,189 & $3,728,282$ & $6,732,212$ \\
\hline 2 & Prov, Sumatera Utara & $2,104,203$ & 64.76 & $1,118,069$ & 34.41 & 317,367 & 754,399 & 46,303 & 1,193 & $3,249,000$ \\
\hline 3 & Prov: Sumatera Barat & 723,758 & 47.49 & 786,523 & 51.62 & 90,501 & 648,943 & 74,179 & & $1,523,896$ \\
\hline 4 & Prov. Piau & $1,276,253$ & 34.84 & $2,386,850$ & 65.16 & $2,188,850$ & 198,000 & & & $3,663,103$ \\
\hline 5 & Prow, Jambi & 480,310 & 38.21 & 776,577 & 61.79 & 267,950 & 473,506 & 35,121 & & $1,256,887$ \\
\hline 6 & Prov. Sumatera Selatan & $1,171,643$ & 43.69 & $1,500,610$ & 55.96 & 993,254 & 507,356 & & & $2,681,672$ \\
\hline 7 & Prov. Bengkulu & 421,731 & 41.88 & 583,034 & 57.89 & 42,417 & 478,339 & 53,277 & & $1,007,090$ \\
\hline 8 & Pros. Lampung & 798,874 & 48.41 & 851,218 & 51.59 & 182,696 & 628,506 & 40,016 & & $1,650,092$ \\
\hline 9 & Prov. DKI Jakarta & $11,134,548$ & 53.86 & $9,540,000$ & 46.14 & $9,540,000$ & & & & $20,674,548$ \\
\hline 10 & Prov. Jawa Barat & $5,176,292$ & 74.46 & $1,763,254$ & 25.35 & 786,017 & 977,238 & & & $6,951,984$ \\
\hline 11 & Prov, Jawa Tengah & $3,624,720$ & 69.59 & $1,583,629$ & 30.41 & 530,137 & $1,053,492$ & & & $5,208,348$ \\
\hline 12 & Proy. DI Yogyakarta & 596,851 & 48.86 & 618,382 & 50.62 & 60,052 & 523,920 & 33,410 & 2,534 & $1,221,594$ \\
\hline 13 & Prov. Jawa Timur & $3,806,986$ & 65.32 & $1,869,633$ & 31.42 & 733,154 & $1,118,478$ & 18,001 & 179,807 & $5,950,572$ \\
\hline 14 & Prow. Kalimantan Barat & 514,889 & 34.83 & 920,965 & 623 & 122,816 & 744,834 & 53,314 & & $1,478,166$ \\
\hline 15 & Proy. Kalimantan Tengah & 502,270 & 32.85 & $1,026,559$ & 67.15 & 272,441 & 694,822 & 59,296 & & $1,528,820$ \\
\hline 16 & Proy. Kalimantan Selatan & 853,488 & 5209 & 756,017 & 46.14 & 229,300 & 483,365 & 43,352 & & $1,538,465$ \\
\hline 13. & Prov. Kalimantan Timur & $1,588,513$ & 31.7 & $3,141,570$ & 62.69 & $3,078,456$ & 63,114 & & & $5,011,283$ \\
\hline 18 & Pros. Sulawei Utara & 309,720 & 30.11 & 668,996 & 65.03 & 57,482 & 558,635 & 52,879 & & $1,028,716$ \\
\hline 19 & Prơ. Sulawesi Tengah & 231,784 & 21.81 & 741,003 & 69.73 & 51,549 & 629,397 & 60,057 & - & $1,062,741$ \\
\hline 20. & Prov: Sulaweri Selatan & $1,301,646$ & 58.91 & 907,819 & 41.09 & 199,548 & 663,422 & 44,849 & & $2,209,465$ \\
\hline 21 & Proy. Sulawesi Tenggara & 472,992 & 37.39 & 728,363 & 57.58 & 82,201 & 589,844 & 56,318 & 63,571 & $1,264,927$ \\
\hline 22 & Prov, Bali & 851,118 & 60.38 & 556,949 & 39.51 & 87,127 & 448,187 & 21,634 & & $1,409,543$ \\
\hline 23 & Prov. Nusa Tenggara Barat & 468,210 & 37.63 & 771,691 & 62.01 & 115,055 & 608,612 & 48,024 & & $1,244,401$ \\
\hline 24 & Prov. Nusa Tenggara Timur & 223,848 & 23.68 & 730,576 & 77.27 & 61,215 & 616,602 & 52,759 & & 945,424 \\
\hline
\end{tabular}




\begin{tabular}{|c|c|c|c|c|c|c|c|c|c|c|}
\hline 25 & Prov. Maluku & 157,725 & 27.21 & 726,011 & 7924 & 79,580 & 578,164 & 68,267 & 20,000 & 916,236 \\
\hline 26 & Prox. Papua & 345,398 & 6.49 & $1,566,891$ & 2944 & 434,000 & $1,058,228$ & 74,663 & $2,609,796$ & $5,322,085$ \\
\hline 27 & Prov. MalukuUtara & 80,630 & II.18 & 611,729 & 84.8 & 93,328 & 458,512 & 59,290 & & 721,409 \\
\hline 28 & Prov, Banten & $1,526,456$ & 68.73 & 690,961 & 31.11 & 297,661 & 361,179 & 32,121 & & $2,220,917$ \\
\hline 29 & Prov. Bangka Belituing & 255,263 & 31.43 & 556,773 & 68.57 & 105,907 & 407,995 & 42,871 & & 812,036 \\
\hline 30 & Prov. Gorcontalo & 76,980 & 144 & 457,525 & 85.6 & 17,854 & 388,325 & 51,346 & & 534,505 \\
\hline 31 & Prov. Kepulauan Riau & 424,587 & 31.93 & 905,313 & 68.07: & 481,250 & 403,132 & 20,931 & & $1,330,000$ \\
\hline 32 & Prov. Papua Barat & 64,920 & 2.25 & 197,780 & 6.86: & 434,200 & 595,000 & 68,580 & $1,718,460$ & 2881,160 \\
\hline \multirow[t]{2}{*}{33} & Prov. Sulawesi Barat & 64,000 & IIIS & 483,914 & 8428 & 26,800 & 391,061 & 66,053 & & 574,142 \\
\hline & & $42,506,578$ & 4432 & $42,733,342$ & 4456 & $23,710,948$ & $18,614,293$ & $\begin{array}{r}1,325 ; \\
100 \\
\end{array}$ & $8,323,643$ & $95,905,448$ \\
\hline
\end{tabular}

Sumber: Pelaksanaan APBD 2009, diolah

\section{Transfer Pusat ke Daerah}

Transfer Dana dari Pemerintah ke Daerah (APBN ke APBD), setiap tahunnya berkisar pada angka $30 \%$ dari Belanja Negara. Pada tahun 2005 , besaran transfer tersebut berada pada angka $29,52 \%$ atau sebesar Rp.150.463,90 (T), tetapi pada tahun berikutnya, yaitu tahun 2006, transfer ke Daerah naik menjadi 33,90\% atau sebesar Rp.266.179,90 (T). Tahun 2009, pada APBN Perubahan, dari sisi prosentase, mengalami peningkatan sebesar $1,23 \%$, tetapi dari sisi nilainya mengalami kenaikan sebesar Rp 16.874,7 (T). Kenaikan nilai tersebut karena belanja Negara juga mengalami peningkatan sebesar Rp.15.113,2 (T). Terakhir pada tahun 2010, besaran transfer ke Daerah adalah sebesar 30,78\% dari Belanja Negara atau sebesar Rp.322.423,00 (T).

Besaran dana transfer dari Pemerintah kepada Daerah tersebut, terbagi atas 33 Provinsi dan 477 Kota dan Kabupaten atau 510 Pemerintah Daerah dengan besaran yang sangat bervariasi.

\section{Dana Perimbangan}

Dana Perimbangan merupakan pendanaan Daerah yang bersumber dari APBN yang terdiri atas Dana Bagi Hasil (DBH), Dana Alokasi Umum (DAU), dan Dana Alokasi Khusus (DAK). Dana Perimbangan selain dimaksudkan untuk membantu Daerah dalam mendanai kewenangannya, juga bertujuan untuk mengurangi ketimpangan sumber pendanaan pemerintahan antara 
Pusat dan Daerah serta untuk mengurangi kesenjangan pendanaan pemerintahan antar-Daerah. Ketiga komponen Dana Perimbangan ini merupakan sistem transfer dana dari Pemerintah serta merupakan satu kesatuan yang utuh. ${ }^{24}$

\subsubsection{Dana Bagi Hasil}

DBH adalah dana yang bersumber dari pendapatan APBN yang dibagihasilkan kepada Daerah berdasarkan angka persentase tertentu. Pengaturan DBH dalam Undang-Undang ini merupakan penyelarasan dengan Undang-Undang Nomor 7 Tahun 1983 tentang Pajak Penghasilan sebagaimana telah beberapa kali diubah, terakhir dengan Undang-Undang Nomor 17 Tahun 2000.

Pengaturan mengenai Bagi Hasil penerimaan Pajak Penghasilan (PPh) Pasal 25/29 Wajib Pajak Orang Pribadi Dalam Negeri dan PPh Pasal 21 serta sektor pertambangan panas bumi sebagaimana dimaksud dalam Undang-Undang Nomor 27 Tahun 2003 tentang Panas Bumi. Selain itu, dana reboisasi yang semula termasuk bagian dari DAK, dialihkan menjadi DBH.

\subsubsection{Dana Alokasi Umum}

DAU bertujuan untuk pemerataan kemampuan keuangan antar-Daerah yang dimaksudkan untuk mengurangi ketimpangan kemampuan keuangan antar-Daerah melalui penerapan formula yang mempertimbangkan kebutuhan dan potensi Daerah. DAU suatu Daerah ditentukan atas besar kecilnya celah fiskal (fiscal gap) suatu Daerah, yang merupakan selisih antara kebutuhan Daerah (fiscal need) dan potensi Daerah (fiscal capacity). ${ }^{25}$

Formula celah fiskal dan penambahan variabel DAU. Alokasi DAU bagi Daerah yang potensi fiskalnya besar tetapi kebutuhan fiskal kecil akan memperoleh alokasi DAU relatif kecil. Sebaliknya, Daerah yang potensi fiskalnya kecil, namun kebutuhan fiskal besar akan memperoleh alokasi DAU relatif besar. Secara implisit, prinsip tersebut menegaskan fungsi DAU sebagai faktor pemerataan kapasitas fiskal.

Besaran DAU yang diatur pada UU 33 Tahun 2004 adalah sekurang-kurangnya $26 \%$ (dua puluh enam persen) dari

\footnotetext{
${ }^{24}$ Op., Cit., UU 33 Tahun 2004, penjelasan.

${ }^{25}$ Op. Cit., UU 33 Tahun 2004, penjelasan.
} 
Pendapatan Dalam Negeri Neto yang ditetapkan dalam APBN. ${ }^{26}$ Dari data yang ada pada tabel 1 , menunjukkan bahwa sejak tahun 2005, DAU yang seharusnya sekurang-kurangnya $26 \%$ dari Pendapatan Dalam Negeri Neto, belum dapat dipenuhi oleh Pemerintah. Pada tahun 2005, DAU yang ditransfer ke Daerah sebesar $17,42 \%$, kemudian meningkat menjadi $21,83 \%$, mengalami sedikit penurunan pada tahun berikutnya yaitu sebesar $21,75 \%$. Pada tahun 2008, persentase DAU tersebut mengalami penurunan sebesar $3,54 \%$, sehingga menjadi $18,21 \%$ dan pada tahun 2009 pada APBN-Perubahan, persentase DAU tersebut mengalami sedikit peningkatan, yaitu sebesar $0,43 \%$ menjadi $18,63 \%$ dari total pendapatan Negara. Pada tahun terakhir, 2010 pada APBN yang telah ditetapkan, persentase DAU mengalami peningkatan sebesar $0,79 \%$ atau menjadi $19,42 \%$.

Besaran DAU yang tidak sesuai yang diamanatkan oleh UU 33 Tahun 2004 memang merupakan masalah tersendiri. DAU yang seharusnya setidaknya $26 \%$, baru terpenuhi pada angka $19,42 \%$ atau kurang $6,58 \%$, suatu angka yang cukup besar, dan bila dihitung berdasarkan APBN 2010, maka besaran kekurangannya adalah Rp.6.889,26 T.

\subsection{Kapasitas Daerah}

Merupakan suatu komponen yang masuk di dalam formula penghitungan Dana Alokasi Umum (DAU). DAU itu sendiri adalah salah satu komponen di dalam Dana Perimbangan di APBN yang pengalokasiannya didasarkan atas FORMULA dengan konsep Kesenjangan Fiskal (Fiscal Gap) yang merupakan selisih antara Kebutuhan Fiskal (Fiscal Need) dengan Kapasitas Fiskal (Fiscal Capacity). DAU bertujuan sebagai instrumen untuk mengatasi masalah horizontal imbalances yang dialokasikan dengan tujuan pemerataan kemampuan Keuangan antar daerah dimana penggunaannya ditetapkan sepenuhnya oleh daerah (block grants). Konsep dasar formulasi DAU sebagaimana yang diamanatkan dalam UU No 25 Tahun 1999 dan kemudian diaur kembali pada UU 33 Tahun 2004, secara implisit merupakan penjabaran dari teori governmental transfer yang 
berbasis pada konsepsi fiscal gap. Dengan konsepsi fiscal gap, nantinya kesenjangan fiskal yang merupakan selisih negatif antara kebutuhan fiskal dengan kapasitas fiskal dianggap sebagai kebutuhan yang harus ditutup melalui transfer Pemerintah Pusat.

Ide dasarnya adalah untuk Daerah yang memiliki kapasitas fiskal relatif lebih besar dibanding kebutuhan fiskalnya, maka DAU yang dialokasikan seyogyanya tidak terlalu besar. Sebaliknya Daerah yang memiliki kebutuhan fiskal relatif lebih tinggi terhadap kapasitas fiskalnya, membutuhkan DAU yang relatif besar pula agar mereka tetap dapat menyediakan pelayanan dasar yang cukup baik. Jadi kapasitas fiskal ini dapat dianggap sebagai wakil kemampuan suatu Daerah di dalam melaksanakan semua kewenangan wajibnya dalam pelaksanaan pemerintahan maupun pembangunan Daerahnya.

\subsection{Kapasitas Fiskal Provinsi}

Kapasitas fiskal adalah gambaran kemampuan keuangan masing-masing Daerah yang dicerminkan melalui penerimaan umum APBD (tidak termasuk dana alokasi khusus, dana darurat, dana pinjaman lama, dan dana penerimaan lain yang penggunaannya dibatasi untuk membiayai pengeluaran tertentu) untuk membiayai tugas pemerintahan setelahd ikurangi belanja pegawai dan dikaitkan dengan jumlah penduduk miskin. ${ }^{27}$

Hasil dari penghitungan kapasitas fiskal Daerah, menjadi dasar pembentukan peta Peta Kapasitas Fiskal Daerah, Provinsi dan Kabupaten/Kota. Peta tersebut sebenarnya adalah pengelompokan Daerah berdasarkan indeks kapasitas fiskal menjadi empat kelompok yaitu Daerah berkapasitas fiskal sangat tinggi, tinggi, sedang dan rendah. $^{28}$

${ }^{27}$ Indonesia, Menteri Keuangan, Peraturan Menteri Keuangan No. 174 Tahun 2009 tentang Peta Kapasitas Daerah, Pasal 1, angka 5.

${ }^{28}$ Ibid., Pasal 1 angka 6. 
Berdasarkan perhitungan dengan rumus:

$\mathrm{KF}=\underline{(\mathrm{PAD}+\mathrm{DBH}+\mathrm{DAU}+\mathrm{LP})-\mathrm{BP}}$

Jumlah penduduk

KF : Kapasitas Fiskal

PAD : Pendapatan Asli Daerah

DBH : Dana Bagi Hasil

DAU : Dana Alikasi Umum

LP : Lain-lain pendapatan Daerah yang sah

BP : Belanja Pegawai

Maka didapatkan peta kapasitas fiskal untuk Provinsi tahun 2010 berdasarkan realisasi Anggaran Tahun 2008

Tabel 3

PETA KAPASITAS FISKAL DAERAH PROVINSI 2010

\begin{tabular}{|l|l|c|c|c|}
\hline No & \multicolumn{1}{|c|}{ PROVINSI } & $\begin{array}{c}\text { Indeks } \\
\text { Kapasitas } \\
\text { Daerah }\end{array}$ & Katergori & Indeks \\
\hline 1 & DKI Jakarta & 7.933 & Sangat Tinggi & $\geq 2$ \\
\hline 2 & Kalimantan Timur & 4.966 & Sangat Tinggi & $\geq 2$ \\
\hline 3 & Kepulauan Riau & 3.133 & Sangat Tinggi & $\geq 2$ \\
\hline 4 & Bangka Belitung & 2.967 & Sangat Tinggi & $\geq 2$ \\
\hline 5 & Kalimantan Selatan & 2.449 & Sangat Tinggi & $\geq 2$ \\
\hline 6 & Bali & 2.116 & Sangat Tinggi & $\geq 2$ \\
\hline 7 & Riau & 2.053 & Sangat Tinggi & $\geq 2$ \\
\hline 8 & Kalimantan Tengah & 1.736 & Tinggi & $1 \leq$ Indeks $<2$ \\
\hline 9 & Maluku Utara & 1.505 & Tinggi & $1 \leq$ Indeks $<2$ \\
\hline 10 & Jambi & 1.382 & Tinggi & $1 \leq$ Indeks $<2$ \\
\hline 11 & Papua Barat & 1.136 & Tinggi & $1 \leq$ Indeks $<2$ \\
\hline 12 & Nangroe Aceh Darusalam & 1.005 & Tinggi & $1 \leq$ Indeks $<2$ \\
\hline 13 & Sumatera Barat & 0.976 & Sedang & $0,5 \leq$ Indeks $<1$ \\
\hline 14 & Sulawesi Utara & 0.897 & Sedang & $0,5 \leq$ Indeks $<1$ \\
\hline 15 & Banten & 0.851 & Sedang & $0,5 \leq$ Indeks $<1$ \\
\hline 16 & Kalimantan Barat & 0.788 & Sedang & $0,5 \leq$ Indeks $<1$ \\
\hline 17 & Sulawesi Barat & 0.786 & Sedang & $0,5 \leq$ Indeks $<1$ \\
\hline 18 & Gorontalo & 0.669 & Sedang & $0,5 \leq$ Indeks $<1$ \\
\hline 19 & Bengkulu & 0.596 & Sedang & $0,5 \leq$ Indeks $<1$ \\
\hline 20 & Sumatera Selatan & 0.582 & Sedang & $0,5 \leq$ Indeks $<1$ \\
\hline 21 & Sumatera Utara & 0.565 & Sedang & $0,5 \leq$ Indeks $<1$ \\
\hline 22 & Sulawesi Selatan & 0.550 & Sedang & $0,5 \leq$ Indeks $<1$ \\
\hline 23 & Sulawesi Tenggara & 0.522 & Sedang & $0,5 \leq$ Indeks $<1$ \\
\hline 24 & Papua & 0.506 & Sedang & $0,5 \leq$ Indeks $<1$ \\
\hline & & & & \\
\hline
\end{tabular}




\begin{tabular}{|l|l|l|l|c|}
25 & Sulawesi Tengah & 0.502 & Sedang & $0,5 \leq$ Indeks $<1$ \\
\hline 26 & DI Yogyakarta & 0.501 & Sedang & $0,5 \leq$ Indeks $<1$ \\
\hline 27 & Maluku & 0.449 & Rendah & $\leq 0,5$ \\
\hline 28 & Jawa Barat & 0.417 & Rendah & $\leq 0,5$ \\
\hline 29 & Jawa Timur & 0.309 & Rendah & $\leq 0,5$ \\
\hline 30 & Nusa Tenggara Timur & 0.297 & Rendah & $\leq 0,5$ \\
\hline 31 & Lampung & 0.287 & Rendah & $\leq 0,5$ \\
\hline 32 & Jawa Tengah & 0.241 & Rendah & $\leq 0,5$ \\
\hline 33 & Nusa Tenggara Barat & 0.224 & Rendah & $\leq 0,5$ \\
\hline
\end{tabular}

Sumber: PMK No. 174 Tahun 2009, diolah

Berdasarkan data peta Kapasitas Fiskal pada tabel 3, maka terlihat, Provinsi dengan Kapasitas Fiskal sangat tinggi ada pada Provinsi DKI Jakarta dengan indeks hamper mencapai 8. Provinsi terdekat adalah Kalimantan Timur dengan jarak indeks sekitar 3 poin. Dua Provinsi baru, yaitu Kepulauan Riau dan Bangka Belitung, termasuk Daerah dengan kapasitas fiskal yang sangat tinggi. Tiga Provinsi di Jawa, Jawa Barat, Jawa Tengah dan Jawa Timur, ternyata termasuk Provinsi dengan kapasitas fiskal yang rendah.

\subsection{Kapasitas Fiskal Daerah Pemekaran 2007}

\section{dan 2008}

Peta Kapasitas fiskal juga terdapat untuk seluruh Kabupaten dan Kota, tetapi karena jumlahnya yang sangat banyak, maka yang akan dibahas di sini hanya Daerahdaerah Kabupaten/Kota hasil pemekaran. Kabupaten/Kota hasil pemekaran tahun 2007, Kabupaten Tana Tidung memiliki kapasitas fiskal yang sangat tinggi, yaitu lebih dari poin 5, sedangkan Kabupaten Pesawaran di Lampung Selatan (dulu merupakan bagian dari), hanya memiliki kapasitas fiskal 0,09 poin saja.

Begitu juga dengan Daerah hasil pemakaran 2008, terdapat dua daerah Kabupaten dengan kapasitas fiskal yang sangat tinggi yaitu Kab. Kepulauan Anambas yang pada awalnya menginduk ke Kab. Natuna dan kaya akan minyak, dengan kapasitas fiskal.10,23 poin dan Kabupaten Meranti yang pada awalnya menginduk pada kebupaten Bengkalis di Provinsi Jambi. Tiga daerah kabupaten hasil pemekaran 2008 juga memiliki indeks kapasitas daerah yang tinggi, yaitu Kabupaten Morotai yang merupakan pecahan dari 
Kabupaten Halmahera Utara Provinsi Maluku Utara dan Kabupaten Tambraw dan Maybrat yang merupakan pecahan dari Kabupaten Sorong di Papua Barat. Untuk Kabupaten hasil pemekaran dengan indeks kapasitas daerah rendah, berjumlah 20 kabupaten (tabel 4).

\section{Tabel 4}

PETA KAPASITAS FISKAL DAERAH PEMEKARAN 2010

\begin{tabular}{|l|l|l|c|c|}
\hline No & \multicolumn{3}{|c|}{$\begin{array}{c}\text { Indeks } \\
\text { Kapasitas } \\
\text { Fiskal } \\
\text { Induk }\end{array}$} & Kategori \\
\hline \multicolumn{5}{|c|}{ Kaerah Pemekaran 2007 } \\
\hline 1 & Kab Tana Tidung & Kab Bulungan & 5.1753 & Sangat Tinggi \\
\hline 2 & Kota Tual & $\begin{array}{l}\text { Kab Maluku } \\
\text { Tenggara }\end{array}$ & 0.4889 & Rendah \\
\hline 3 & Kab Kubu Raya & Kab Pontianak & 0.4593 & Rendah \\
\hline 4 & Kab Padang Lawas Utara & $\begin{array}{l}\text { Kab Tapanuli } \\
\text { Selatan }\end{array}$ & 0.3550 & Rendah \\
\hline 5 & Kab Padang Lawas & $\begin{array}{l}\text { Kab Tapanuli } \\
\text { Selatan }\end{array}$ & 0.3550 & Rendah \\
\hline 6 & Kota Serang & Kab Serang & 0.3414 & Rendah \\
\hline 7 & Kab Manggarai Timur & Kab Manggarai & 0.1525 & Rendah \\
\hline 8 & Kab Pesawaran & $\begin{array}{l}\text { Kab Lampung } \\
\text { Selatan }\end{array}$ & 0.0989 & Rendah \\
\hline \multicolumn{5}{|c|}{ Daerah Pemekaran 2008 } \\
\hline 1 & Kab Kepulauan Anambas & Kab Natuna & 10.2702 & Sangat Tinggi \\
\hline 2 & Kab Kepulauan Meranti & Kab Bengkalis & 3.6035 & Sangat Tinggi \\
\hline 3 & Kab Pulau Morotai & $\begin{array}{l}\text { Kab Halmahera } \\
\text { Utara }\end{array}$ & 1.7389 & Tinggi \\
\hline 4 & Kab Tambrauw & Kab Sorong & 1.3084 & Tinggi \\
\hline 5 & Kab Maybrat & Kab Sorong & 1.3084 & Tinggi \\
\hline 6 & Kab Puncak & Kab Puncak Jaya & 0.9190 & Sedang \\
\hline 7 & Kab Intan Jaya & Kab Paniai & 0.8189 & Sedang \\
\hline 8 & Kab Deiyai & Kab Paniai & 0.8189 & Sedang \\
\hline 9 & Kota Sungai Penuh & Kab Kerinci & 0.7412 & Sedang \\
\hline 10 & Kab Buru Selatan & Kab Buru & 0.6685 & Sedang \\
\hline 11 & Kab Dogiyai & Kab Nabire & 0.5965 & Sedang \\
\hline 12 & Kab Maluku Barat Daya & $\begin{array}{l}\text { Kab Maluku } \\
\text { Tenggara Barat }\end{array}$ & 0.5445 & Sedang \\
\hline 13 & Kab Mesuji & $\begin{array}{l}\text { Kab Tulang } \\
\text { Bawang }\end{array}$ & 0.4547 & Rendah \\
\hline 14 & Kab Tulang Bawang Barat & Kab Tulang Bawang & 0.4547 & Rendah \\
\hline
\end{tabular}




\begin{tabular}{|l|l|l|c|c|}
\hline No & \multicolumn{1}{|c|}{ DAERAH } & Kabupaten Asal & $\begin{array}{c}\text { Indeks } \\
\text { Kapasitas } \\
\text { Fiskal } \\
\text { Induk }\end{array}$ & Kategori \\
\hline 15 & Kab Bengkulu Tengah & $\begin{array}{l}\text { Kab Bengkulu } \\
\text { Utara }\end{array}$ & 0.4147 & Rendah \\
\hline 16 & $\begin{array}{l}\text { Kab Bolaang Mongondow } \\
\text { Timur }\end{array}$ & $\begin{array}{l}\text { Kab Bolaang } \\
\text { Mongondow }\end{array}$ & 0.3683 & Rendah \\
\hline 17 & $\begin{array}{l}\text { Kab Bolaang Mongondow } \\
\text { Selatan }\end{array}$ & $\begin{array}{l}\text { Kab Bolaang } \\
\text { Mongondow }\end{array}$ & 0.3683 & Rendah \\
\hline 18 & Kota Tangerang Selatan & Kab Tangerang & 0.3609 & Rendah \\
\hline 19 & Kab Labuhan Batu Selatan & Kab Labuhan Batu & 0.3499 & Rendah \\
\hline 20 & Kab Labuhan Batu Utara & Kab Labuhan Batu & 0.3499 & Rendah \\
\hline 21 & Kab Sigli & Kab Donggala & 0.3126 & Rendah \\
\hline 22 & Kab Membaramo Tengah & Kab Jayawijaya & 0.2895 & Rendah \\
\hline 23 & Kab Yalimo & Kab Jayawijaya & 0.2895 & Rendah \\
\hline 24 & Kab Lanny Jaya & Kab Jayawijaya & 0.2895 & Rendah \\
\hline 25 & Kab Nduga & Kab Jayawijaya & 0.2895 & Rendah \\
\hline 26 & Kab Sabu Raijua & Kab Kupang & 0.2552 & Rendah \\
\hline 27 & Kab Toraja Utara & Kab Tana Toraja & 0.2412 & Rendah \\
\hline 28 & Kab Nias Utara & Kab Nias & 0.2357 & Rendah \\
\hline 29 & Kab Nias Barat & Kab Nias & 0.2357 & Rendah \\
\hline 30 & Kota Gunung Sitoli & Kab Nias & 0.2357 & Rendah \\
\hline 31 & Kab Pringsewu & Kab Tanggamus & 0.1367 & Rendah \\
\hline 32 & Kab Lombok Utara & Kab Lombok Barat & 0.0986 & Rendah \\
\hline
\end{tabular}

Sumber: PMK No. 174 Tahun 2009

\subsubsection{Dana Alokasi Khusus}

DAK dimaksudkan untuk membantu membiayai kegiatan-kegiatan khusus di Daerah tertentu yang merupakan urusan Daerah dan sesuai dengan prioritas nasional, khususnya untuk membiayai kebutuhan sarana dan prasarana pelayanan dasar masyarakat yang belum mencapai standar tertentu atau untuk mendorong percepatan pembangunan Daerah. ${ }^{29}$

DAK yang ditransfer ke Daerah tidaklah besar bila dilihat dari persentase Dana Perimbangan yang ditransfer secara keseluruhan. Data pada Tabel 1 menunjukkan bahwa pada tahun 2005, nilai DAK adalah Rp.3,976 T atau sebesar 2,64\% saja dari 
seluruh dana yang ditransfer ke Daerah yang senilai Rp 150.436 $\mathrm{T}$. Tahun berikutnya, terjadi kenaikan yang cukup tinggi, yaitu sebesar 2,47\%, sehingga menjadi 5,11\% atau senilai Rp $11.566 \mathrm{~T}$ dari keseluruhan dana perimbangan sebesar Rp.226,179 T.

Tahun 2007, dari sisi persentase, mengalami peningkatan sebesar $1,3 \%$ dari tahun sebelumnya, dan dari sisi nilainya mengalami peningkatan sebesar Rp.27.083,2 T dari total dana perimbangan senilai Rp.253.263 T. Tahun berikutnya, 2008 , terjadi peingkatan kembali sebesar $0.7 \%$ atau DAK senilai Rp.20.787 T dari total dana perimbangan Rp.292.433 T. DAK kembali meningkat pada tahun 2009 , menjadi $8,02 \%$ atau senilai Rp.24.819 T dari total dana perimbangan sebesar Rp.309.308 T. Terakhir pada 2010, pada APBN yang telah ditetapkan, DAK mengalami penurunan sebesar $1,47 \%$ atau menjadi hanya $6,55 \%$ atau senilai Rp.21.133 $\mathrm{T}$ dari total dana perimbangan yang sebesar Rp.322.423 T.

\subsubsection{Dana Otonomi Khusus dan Penyesuaian}

\subsubsection{Dana Otonomi Khusus}

Dana Bagi Hasil sebagaimana diatur dalam Undang-Undang Nomor 18 Tahun 2001 tentang Otonomi Khusus Provinsi Nanggroe Aceh Darussalam dan Undang-Undang Nomor 21 Tahun 2001 tentang Otonomi Khusus Provinsi Papua dan Papua Barat. Dana Otonomi Khusus, yang tidak diatur pada UU 33 Tahun 2004 ini, jumlahnya cukup besar dan dari tahun ketahun mengalami peningkatan.

Dana Otonomi Khusus pada tahun 2005 senilai Rp.1,775 T atau sebesar $1,18 \%$ dari total dana perimbangan yang ditransfer ke Daerah yang sebesar Rp.226,179 T. Tahun berikutnya, 2006, dana Otonomi Khusus mengalami peningkatan sebesar 0,36\% menjadi sebesar $1,54 \%$ atau senilai Rp.3,488 $\mathrm{T}$ yang dari sisi nilai sebenarnya cukup besar. Dana kemudian meningkat lagi pada tahun 2007 , tidak besar, hanya $0,06 \%$ sehingga menjadi $1,60 \%$ atau senilai Rp.4.045 $\mathrm{T}$ dari total dana perimbangan yang nilainya Rp.253.263 T.

Kenaikan sebesar $0,97 \%$ terjadi pada tahun berikutnya, yaitu tahun 2008. Nilai rupiahnya menjadi Rp.7.510 T atau sebesar $2,57 \%$ dari dana perimbangan yang ditransfer ke Daerah pada tahun anggaran tersebut. Pada APBN-P 2009, persentase meningkat $0.51 \%$, tetapi nilai rupiahnya cukup besar, yaitu $\mathrm{Rp}$ 
9.526 T yang terbagi atas Provinsi Nangroe Aceh Darusalam seńilai Rp.3.728 T, Provinsi Papua senilai Rp.2.609.796 dan Provinsi Papua Barat senilai Rp.1.718 T (data ada pada tabel 2). Untuk tahun 2010, APBN menetapkan bahwa Dana Otonomi Khusus senilai Rp.9.099 T, yang artinya angka tersebut sebesar $2,82 \%$ dari keseluruhan dana perimbangan yang ditransfer ke Daerah.

\subsubsection{Dana Penyesuaian}

Dana Penyesuaian diberikan nila pada tahun anggaran 2007, DAU untuk Provinsi tertentu lebih kecil dari DAU pada tahun anggaran 2005, maka diberikanlah dana tersebut yang besarnya sesuai dengan kemampuan dan perekonomian Negara. Pada tabel 1 , sudah menunjukkan berapa dana penyesuaian yang diberikan oleh Pemerintah kepada Daerah. Dana penyesuaian pada tahun 2007 yang ditransfer pada Daerah adalah senilai Rp.5,250 T, kemudian meningkat menjadi Rp.6,208 T pada tahun 2008, kemudian melonjak 42,15\% pada APBN-P tahun 2009 atau menjadi senilai Rp.14,728 T. Di tahun 2010, Dana Penyesuaian ditetapkan dalam APBN senilai Rp.7,300 $\mathrm{T}$ atau mengalami penurunan sebesar $201,76 \%$.

\section{Penutup}

\section{A. Kesimpulan}

1. Dari berbagai permasalahan yang muncul mengenai transfer daerah dalam bentuk dana perimbangan, maka besaran persentase transfer kepada daerah rata-rata pertahun berkisar pada angka $30 \%$.

2. Bila angka tersebut dilihat secara kumulatif baik persentase maupun nilainya, adalah sepertiga dari total anggaran Negara setiap tahunnya. Suatu angka yang relatif kecil, mengingat Daerah pada saat ini dibebani urusan-urusan wajib yang sangat banyak jumlahnya dengan "ancaman-ancaman" tertentu bila tidak melaksanakannya.

3. Bila dilihat perbagian, yaitu DBH, DAU, DAK, DP, DOtsus, maka pada DAu Pemerintah masih belum dapat memenuhi kewajiban yang ditetapkan oleh UU 33 Tahun 2004, yaitu DAu 
setelah tahun 2007, sekurang-kurangnya $26 \%$ dari total Pendapatan Dalam Negeri Neto yang ditetapkan dalam APBN.

B. Saran

1. Pemekaran daerah merupakan salah satu beban anggaran Negara untuk meningkatkan dana perimbangan, khususnya Dana Alokasi Umum, karena meskipun pemekaran juga telah melewati berbagai syarat dan petimbangan, maka membengkaknya Daerah mengakibatkan beban anggaran menjadi semakin berat.

2. Dari data kapasitas fiskal yang ada untuk kabupaten/kota, $62 \%$ memiliki indeks kapasitas yang rendah, dan hanya dua yang sangat tinggi dan tiga yang tinggi. Hal tersebut menunjukkan bahwa Daerah-daerah pemekaran tersebut membebani anggaran Negara secara keseluruhan.

3. Harapannya adalah, pemekaran tersebut makin mendekatkan pelayanan publik kepada masyarakat, walaupun kapasitas fiskal daerahnya sangat terbatas. 


\section{Daftar Pustaka}

Indonesia, Undang-undang No. 17 Tahun 2003 tentang Keuangan Negara

Indonesia, Undang-undang No. 32 Tahun 2004 tentang Pemerintahan Daerah Indonesia, Undang-undang No. 33 Tahun 2004 tentang Perimbangan Keuangan antara Pemerintah Pusat dan Pemerintah Daerah.

Indonesia, Menteri Keuangan, Peraturan menteri Keuangan No. 174 Tahun 2009 tentang Peta Kapasitas Fiskal Daerah

Adriansyah. Perimbangan Keuangan Pusat dan Daerah dalam Kerangka Pelaksanaan Otda, tahun 2003.

Arsjad, Nurdjaman, Bambang Kusumanto dan Yiwono Prawirosetoto. Keuangan Negara, Jakarta: Intermedia, 1992.

Bird, Richard M and Francois Vaillancourt. Fiscal Decentralization in Developing Countries, Jakarta: Gramedia. 2000.

Devas, Nick, Brian Binder, and Anne Both, et.all. Keuangan Pemerintah Daerah di Indonesia, Jakarta: UIP, 1989.

Habirono, Haryo. Perda VS Aspirasi Masyarakat, Jakarta 2002.

Hakim, Abdul. Akuntansi Keuangan Daerah, Jakarta: Salemba Empat, 2002

Hoessein, Bhenyamin. Perspektif Jangka Panjang Desentralisasi dan Otda, 2002.

Hoessein, Bhenyamin. Berbagai Faktor Yang Mempengaruhi Besarnya Otonomi Daerah Tingkat II, Suatu Kajian Desentralisasi Dan Otonomi Daerah Dari Segi Ilmu Administrasi, Disertasi Pascasarjana Universitas Indonesia, 1993

Honein, Asri. Evaluasi Perda Pajak dan Retribusi, Jakarta 2003.

Ismail, Munawar. "Pendapatan Asli Daerah dalam Otonomi Daerah, 2002.

Ismail, Tjip. Kebijakan Pajak Daerah dan Retribusi Daerah, Jakarta 2002.

Mardiasmo. Otonomi dan Manajemen Keuangan Daerah, Yogyakarta: Andi, 2002

Marulitua, Sahat. Teknis Penyusunan RPJM Daerah Paska Pilkada dan Penjabarannya ke dalam Renstra SKPD, Direktorat Perencanaan Pembangunan Darah, Depdagri, 2004.

Nugraha, Safri. Hukum Administrasi Daerah, Jakarta: CLGS, 2007. 
Pakpahan, Arlen. "Upaya Pencapaian Good Governance dalam Pengelolaan Keuangan Daerah", Forum Inovasi, Vol. 5: Desember - Februari 2003.

Pusat Studi Ekonomi dan kebijakan Publik UGM. "Penyusunan Anggaran (RAPBD) berdasarkan Pendekatan Kinerja," Yogyakarta: Modul Workshop, 2002.

Sidik, Machfud. "Implementasi UU No 25 tahun 1999 tentang Perimbangan Keuangan Pusat dan Daerah", Jakarta 2002. . Raksaka Mahi, Robert Simandjuntak dkk, Dana Alokasi Umum. Jakarta: Kompas, 2002. 